\title{
MODEL KOREKSI KESALAHAN (ECM) PADA KASUS DATA RUNTUN WAKTU INDEKS HARGA KONSUMEN DI JAWA TENGAH
}

\author{
Mega Sari, Evy Sulistianingsih \\ INTISARI
}

\begin{abstract}
Model koreksi kesalahan (ECM) berfungsi untuk membentuk hubungan jangka panjang, mengoreksi ketidakseimbangan jangka pendek, mengatasi masalah data runtun waktu yang tidak stasioner dan mengatasi masalah regresi lancung (spurious regression). Diperlukan lima langkah dalam model koreksi kesalahan yaitu melakukan uji akar unit (ADF), melakukan uji kointegrasi Engle-Granger, estimasi model koreksi kesalahan Engle Granger dan Domowitz-Elbadawi, melakukan signifikan parameter, dan pemilihan model yang terbaik dengan membandingkan kriteria nilai AIC. Penelitian ini bertujuan untuk menerapkan model koreksi kesalahan pada kasus data runtun waktu indeks harga konsumen (IHK) di Jawa Tengah dan membandingkan model koreksi kesalahan Engle Granger dan Domowitz-Elbadawi dengan menggunakan kriteria pembanding nilai AIC. Data yang digunakan dalam penelitian ini merupakan data sekunder yang diperoleh dari BPS berupa data bulanan IHK berdasarkan empat kelompok pengeluaran dari tahun 2014 sampai dengan tahun 2017. Hasil penelitian menunjukkan bahwa penerapan model koreksi kesalahan yang digunakan adalah valid (sesuai) dan perbandingan menggunakan nilai AIC dari kedua model koreksi kesalahan diperoleh model koreksi kesalahan Engle Granger mempunyai kemampuan yang baik. Perolehan nilai AIC pada model koreksi kesalahan untuk masing-masing data IHK berdasarkan empat kelompok pengeluaran sebesar 0,4399 dan 1,1601 yang menunjukkan model koreksi kesalahan Engle Granger merupakan model yang lebih baik digunakan dari model koreksi kesalahan Domowitz-Elbadawi.
\end{abstract}

Kata Kunci : Uji Akar Unit, Kointegrasi, Model Koreksi Kesalahan (ECM)

\section{PENDAHULUAN}

Pada analisis data runtun waktu, sering didapat data yang digunakan tidak stasioner sehingga dapat menghasilkan regresi lancung (spurious regression). Masalah regresi lancung bisa hilang jika variabel $Y_{t}$ dan $X_{t}$ yang diamati saling berkointegrasi[1]. Jika kedua variabel terdapat kointegrasi yang berarti memiliki hubungan keseimbangan jangka panjang, dapat dibentuk model yang tepat untuk digunakan yaitu model koreksi kesalahan (ECM). Model koreksi kesalahan digunakan untuk membentuk hubungan jangka panjang, mengoreksi ketidakseimbangan jangka pendek, mengatasi masalah data runtun waktu yang tidak stasioner dan masalah regresi lancung[2]. Model koreksi kesalahan dapat diturunkan melalui dua pendekatan yaitu model koreksi kesalahan Engle Granger dan model koreksi kesalahan Domowitz-Elbadawi[3].

Penelitian ini menerapkan model koreksi kesalahan pada kasus data runtun waktu indeks harga konsumen (IHK) serta membandingkan model koreksi kesalahan Engle Granger dan model koreksi kesalahan Domowitz-Elbadawi dengan menggunakan kriteria pembanding nilai AIC. Dalam penelitian ini digunakan empat kelompok IHK yaitu makanan jadi, sandang, kesehatan dan transportasi[4]. Model dalam penelitian ini terbatas menggunakan data runtun waktu yang stasioner dan untuk model koreksi kesalahan yaitu model koreksi kesalahan Engle Granger dan Model koreksi kesalahan Domowitz-Elbadawi.

Data yang digunakan merupakan data sekunder yang diperoleh dari BPS di Kota Purwokerto Provinsi Jawa Tengah[4]. Pemeriksaan kestasioneritas terhadap data adalah dengan menggunakan uji akar unit (ADF). Kemudian, dilakukan uji kointegrasi Engle-Grenger dan estimasi model koreksi kesalahan Engle Granger dan model koreksi kesalahan Domowitz-Elbadawi. Langkah selanjutnya melakukan uji signifikansi parameter dengan uji $\mathrm{F}$ dan uji $\mathrm{T}$. Setelah diperoleh variabel-variabel yang mempengaruhi variabel independen secara bersama-sama maupun secara individual. Langkah yang terakhir melakukan pemilihan model yang terbaik dengan membandingkan kedua model koreksi kesalahan Engle Granger dan Domowitz-Elbadawi dengan menggunakan kriteria nilai AIC. 


\section{UJI AKAR UNIT (Unit Root Test)}

Uji akar unit dalam data runtun waktu merupakan langkah awal untuk mengetahui apakah data sudah stasioner atau tidak stasioner, agar menghasilkan model yang baik untuk digunakan. Uji akar unit digunakan model berikut:

$$
Y_{t}=\rho Y_{t-1}+e_{t} \quad-1 \leq \rho \leq
$$

dimana $Y_{t}$ adalah data pada waktu ke- $t ; p$ adalah koefisien model ADF dan $\varepsilon_{t}$ adalah residual pada waktu ke- $t$ yang bersifat acak dengan rata-rata nol, varians yang konstan dan tidak terdapat autokolerasi. Residual yang mempunyai sifat tersebut disebut residual yang white noise.

Jika $\rho=1$ maka $Y_{\text {r }}$ dapat dikatakan variabel acak dan $Y_{z}$ mempunyai akar unit. Jika data runtun waktu terdapat akar unit, maka data yang diamati tidak stasioner[3]. Dari persamaan (1) diperoleh:

$$
\begin{gathered}
Y_{t}-Y_{t-1}=\rho Y_{t-1}-Y_{t-1}+e_{t} \\
\Lambda Y_{\varepsilon}=(\rho-1) Y_{t-1}+e_{\varepsilon} \\
\Delta Y_{t}=S Y_{t-1}+e_{t}
\end{gathered}
$$

Pengujian ketidakstasioneran dapat dilakukan dengan mengestimasi persamaan (1) dan menguji apakah $\rho=1$ atau dengan mengestimasi Persamaan (3) dan menguji apakah $\delta=0$. Dickey Fuller menunjukkan bahwa nilai koefisien $\delta$ akan mengikuti distribusi statistik $t$ dan menyusun statistik $t$ sebagai titik kritis pengujian. Model sederhana yang digunakan adalah dengan menambahkan konstanta $\beta_{1}$ pada Persamaan (3) yaitu $\Delta Y_{t}=\beta_{1}+\delta Y_{t-1}+e_{t}$. Pengujian ADF dilakukan dengan menghitung nilai t-statistik dengan rumus $t=\frac{\rho}{s E(\rho]}$ [5]. Hipotesis yang di uji adalah sebagai berikut:

$$
\begin{aligned}
& H_{0}: \delta=0 \text { (terdapat akar unit atau data tidak stasioner) } \\
& H_{1}: \delta<0 \text { (tidak terdapat akar unit atau data stasioner) }
\end{aligned}
$$

Kaidah keputusan yang digunakan adalah tolak $H_{0}$, jika nilai ADF $t$ - statistik $<$ nilai kritis Mckinnon atau Prob. $<5 \%$. Berarti data tidak terdapat akar unit atau data stasioner. Terima $H_{0}$ jika nilai ADF $t-$ statistik $>$ nilai kritis Mckinnon atau Prob. $\geq 5 \%$. Berarti data terdapat akar unit atau tidak stasioner.

\section{UJI KOINTEGRASI ENGLE-GRANGER}

Data runtun waktu yang mengalami kasus regresi lancung, tidak perlu dilakukan analisis regresi diantara variabel $Y_{t}$ dan $X_{t}$, jika $Y_{t}$ dan $X_{t}$ masing-masing memiliki akar unit, kecuali pada keadaan $Y_{t}$ dan $X_{t}$ berkointegrasi. Jika terjadi kointegrasi maka masalah regresi lancung akan hilang dan terdapat hubungan keseimbangan antara $Y_{\mathrm{t}}$ dan $X_{\mathrm{t}}[1]$. Pada keadaan di mana data yang saling berkointegrasi, dapat ditulis persamaan sebagai berikut:

$$
Y_{t}=\alpha+\beta X_{t}+e_{t}
$$

Dengan didefinisikan $e_{t}$ sebagai residual kesalahan ketidakseimbangan dari model regresi linear sederhana antara $Y_{t}$ dan $X_{t}$, sehingga:

$$
e_{t}=Y_{t}-\alpha-\beta X_{t}
$$

Jika uji stasioneritas residual kesalahan ketidakseimbangan $\left(e_{t}\right)$ menunjukkan tidak terdapat akar unit atau data stasioner, dapat dikatakan bahwa Persamaan (5) antar variabel $Y_{t}$ dan $X_{t}$ berkointegrasi yang berarti data mempunyai hubungan keseimbangan jangka panjang[1]. 


\section{MODEL KOREKSI KESALAHAN ENGLE GRANGER}

Konsep dasar dalam menentukan estimasi model koreksi kesalahan Engle Granger terlebih dahulu menentukan variabel $Y_{t}$ dan $X_{t}$ saling berkointegrasi atau menggambarkan hubungan keseimbangan. Jika kedua variabel tersebut berkointegrasi, maka terdapat hubungan keseimbangan jangka panjang. Dalam jangka pendek, mungkin terdapat ketidakseimbangan antara variabel $Y_{t}$ dan $X_{t}$. Kesalahan ketidakseimbangan dalam jangka panjang $e_{t}$ dapat digunakan untuk mengikat perilaku jangka pendek dengan estimasi model koreksi kesalahan (ECM) yang diperkenalkan oleh Sargan dan dipopulerkan oleh Engle Granger (1987)[6]. Model koreksi kesalahan mempunyai beberapa kegunaan utama yaitu untuk membentuk model hubungan jangka panjang, mengoreksi ketidakseimbangan jangka pendek, mengatasi masalah data runtun waktu yang tidak stasioner dan masalah regresi lancung. Misalkan hubungan jangka panjang atau keseimbangan antara variabel $Y_{t}$ dan $X_{t}$ adalah sebagai berikut:

$$
Y_{t}=\beta_{0}+\beta_{1} X_{t}+e_{t}
$$

di mana $Y_{\varepsilon}$ adalah variabel dependen; $\beta_{1}$ adalah koefisien jangka panjang; $X_{l}$ adalah variabel independen.

Jika $Y_{t}$ berada pada titik keseimbangan terhadap $X_{t}$ maka keseimbangan antara dua variabel $Y_{t}$ dan $X_{t}$ pada Persamaan (6) mempunyai kesalahan ketidakseimbangan sebesar:

$$
e_{t}=Y_{t} \quad \beta_{0} \beta_{1} X_{t}
$$

di mana $e_{t}$ adalah residual

Jika $Y_{t}$ dan $X_{t}$ dalam kondisi keseimbangan, maka kesalahan ketidakseimbangan tersebut akan bernilai nol. Model koreksi kesalahan Engle Granger dijelaskan sebagai berikut:

$$
\Delta Y_{z}=\alpha_{0}+\alpha_{1} \Delta X_{z}+\kappa_{2} E C_{z}+e_{\tau}
$$

di mana $\Delta$ adalah pembedaan; $E C_{t}$ adalah $\lambda Y_{t-1}-\beta_{0}-\beta_{1} X_{t-1} ; \Delta X_{t}$ adalah $X_{t}-X_{t-1} ; \alpha_{1}$ adalah koefisien jangka pendek; $\beta_{1}$ adalah koefisien jangka panjang; $\alpha_{2}$ adalah koefisien koreksi ketidakseimbangan.

Koefisien koreksi ketidakseimbangan $\alpha_{2}$ adalah bentuk nilai absolut yang menjelaskan seberapa cepat waktu yang diperlukan untuk mendapat nilai keseimbangan. Apabila nilai probabilitas dari koefisien $\alpha_{2}$ lebih kecil dari 0,05 maka model koreksi kesalahan Engle Granger teridentifikasi mempunyai hubungan jangka pendek[3].

\section{MODEL KOREKSI KESALAHAN DOMOWITZ-ELBADAWI}

Setelah model koreksi kesalahan Engle Granger muncul, kemudian model koreksi kesalahan dikembangkan oleh para ahli ekonometrika, salah satunya adalah Domowitz-Elbadawi. Model ini didasarkan pada kenyataan bahwa perekonomian berada dalam kondisi ketidakseimbangan[3]. Misalkan hubungan jangka panjang atau keseimbangan antara variabel $Y_{t}$ dan $X_{t}$ sebagai berikut:

$$
Y_{t}^{*}+\varphi_{1} X_{t}+e_{t}
$$

di mana $Y_{t}^{*}$ adalah nilai keseimbangan; $\varphi_{1}$ adalah koefisien jangka panjang.

Apabila $Y_{t}$ mempunyai nilai yang berbeda dengan nilai keseimbangannya maka besarnya ketidakseimbangannya sebesar:

$$
E C_{t}=Y_{t}^{*}-\varphi_{0}-\varphi_{1} X_{\tau}
$$

Model koreksi kesalahan Domowitz-Elbadawi adalah sebagai berikut:

$$
\Delta Y_{t}=g_{0}+g_{1} \Delta X_{t}+g_{2} X_{t-1}+g_{3} E C_{t-1}+\varepsilon_{t}
$$

di mana $\Delta$ adalah pembedaan; $Y_{t}$ adalah nilai variabel dependen dari $Y$ pada waktu ke-t; $g_{\mathrm{n}}$ adalah koefisien jangka pendek; $X_{t}$ adalah nilai variabel dependen dari $X$ pada waktu ke-t; $E C_{:-1}$ adalah variabel koreksi kesalahan periode sebelumnya. Model koreksi kesalahan Domowitz-Elbadawi dengan koefisien koreksi kesalahan bertanda negatif dan secara statistik signifikan. Model ini valid jika diketahui variabel-variabel yang diamati berkointegrasi. Hal ini ditunjukkan oleh nilai koefisien $E C_{t-1}$ 
dan secara statistik signifikan. Nilai koefisien koreksi kesalahan terletak diantara $0<g_{3}<1$. Koefisien $g$ pada persamaan (14) merupakan analisis jangka pendek[3].

\section{UJI SIGNIFIKANSI PARAMETER}

Setelah menentukan estimasi model koreksi kesalahan Engle Granger dan model koreksi kesalahan Domowitz-Elbadawi terhadap variabel dependen dan independen pada model koreksi kesalahan. Selanjutnya, dilakukan uji signifikansi parameter dengan hipotesis penelitian yaitu hipotesis nol $\left(I_{0}\right)$ dan hipotesis alternatif $\left(H_{1}\right)$. Dalam menguji kebenaran data, terdapat dua uji yaitu uji $\mathrm{F}$ dilakukan untuk mengetahui apakah variabel independen berpengaruh secara bersama-sama dan uji $\mathrm{T}$ untuk mengetahui pengaruh variabel independen secara individual [3].

\section{PEMILIHAN MODEL YANG TERBAIK}

Pemilihan model yang terbaik dilakukan dengan membandingkan model koreksi kesalahan Engle Granger dan model koreksi kesalahan Domowitz-Elbadawi menggunakan kriteria pembanding nilai AIC. Model terbaik adalah model yang menggunakan nilai AIC paling kecil [7].

$$
A I C=\frac{e^{2 k / n} \sum_{i=1}^{n} \hat{u}_{i}^{2}}{n}
$$

dengan $k$ merupakan jumlah parameter yang di estimasi dalam model; $n$ adalah jumlah observasi, $\mathrm{e}=$ $2,178 \ldots$ dan $\widehat{u}_{i}$ adalah residual ke-i.

\section{HASIL DAN PEMBAHASAN}

Data yang digunakan dalam penelitian ini adalah data sekunder indeks harga konsumen (IHK) di Kota Purwokerto yang diperoleh dari BPS Provinsi Jawa Tengah. BPS (2018) membagi laju inflasi harga konsumen perbulan menurut kelompok pengeluaran salah satunya yaitu makanan jadi, sandang, kesehatan dan transportasi yang berjumlah 48 data dari bulan Januari 2014 sampai dengan bulan Desember 2017. Variabel yang digunakan adalah makanan jadi $(Y)$, sandang $\left(X_{1}\right)$, kesehatan $\left(X_{2}\right)$, dan transportasi $\left(X_{3}\right)$.

Langkah pertama dilakukannya uji akar unit (ADF) dan diperoleh untuk masing-masing variabel memiliki nilai ADF $t$ - statistik lebih kecil dari nilai kritis Mckinnon atau Prob. $<5 \%$, maka tolak $H_{0}$ yang berarti data tidak terdapat akar unit atau data stasioner. Dengan kata lain, masing-masing variabel untuk data IHK berdasarkan empat kelompok pengeluaran pada orde nol dapat disimpulkan bahwa tidak terdapat akar unit atau data stasioner. Langkah selanjutnya melakukan identifikasi model apakah data saling berkointegrasi. Digunakan uji kointegrasi Engle-Granger untuk menguji adanya kointegrasi.

Pada pengujian kointegrasi Engle-Granger diperoleh nilai residual kesalahan ketidakseimbangan $e_{t}$ atau residual (-1) menunjukkan tidak terdapat akar unit atau data stasioner, sehingga dapat dikatakan bahwa residual (-1) yang dihasilkan data saling berkointegrasi. Berarti dalam jangka panjang terjadi keseimbangan antara variabel dependen dan variabel independen yang diamati. Diperoleh hasil estimasi persamaan jangka panjang sebagai berikut:

$$
Y_{t}=0,2336+0,5688 X_{1_{t}}+0,2316 X_{2_{t}}-0,0137 X_{3 t}
$$

Karena data IHK di Kota Purwokerto telah stasioner dan saling berkointegrasi maka hubungan antara keduanya dapat dijelaskan dengan model koreksi kesalahan (ECM). 
Pada penelitian ini, diperoleh hasil estimasi model koreksi kesalahan Engle Granger adalah sebagai berikut :

$$
\Delta Y_{t}=-0,0044+0,5473 \Delta X_{1_{t}}-0,0509 X_{3_{t}}-0,7092 E C_{t}
$$

Sedangkan model koreksi kesalahan Domowitz-Elbadawi adalah sebagai berikut :

$$
\Delta Y_{t}=0,1417+0,5172 \Delta X_{1}-0,2145 \Delta X_{3_{t}}-0,4583 X_{1_{t-1}}-0,0841 X_{3_{t-1}}+0,2023 E C_{t-1}
$$

Berdasarkan hasil estimasi model koreksi kesalahan Engle Granger, diperoleh nilai error model Engle Granger atau residual $(-1)$ sebesar $(-0,709217)$ bertanda negatif dan signifikan, yang berarti model spesifikasi pada model koreksi kesalahan yang digunakan dalam penelitian adalah valid. Dengan koefisien koreksi ketidakseimbangan residual (-1) lebih kecil dari 0,05 maka teridentifikasi mempunyai hubungan jangka pendek. Dari estimasi model koreksi kesalahan dalam jangka pendek variabel independen berpengaruh secara signifikan terhadap variabel $Y_{t}$. Sedangkan, model koreksi kesalahan Domowitz-Elbadawi diperoleh nilai koefisien $E C_{t-:}$ atau error model Domowitz-Elbadawi sebesar 0,202383 bertanda positif dan signifikan yang berarti model spesifikasi model koreksi kesalahan yang digunakan dalam penelitian adalah valid. Hasil estimasi memperlihatkan bahwa dalam jangka pendek variabel independen yang digunakan berpengaruh secara signifikan terhadap variabel $Y_{*}$.

Untuk membandingkan kedua model koreksi kesalahan yang terbaik dari data runtun waktu IHK digunakan kriteria pembanding nilai AIC. Hasil perbandingan dapat dilihat pada Tabel 1 sebagai berikut:

Tabel 1. Nilai AIC dari Model Koreksi Kesalahan Engle Granger dan Domowitz-Elbadawi

\begin{tabular}{ccc}
\hline & \multicolumn{2}{c}{ Model Koreksi Kesalahan } \\
\hline \multirow{2}{*}{ Data } & \multicolumn{2}{c}{ NILAI AIC } \\
\cline { 2 - 3 } & Engle Granger & Domowitz-Elbadawi \\
\hline 1 & 0,4399 & 1,1601 \\
\hline
\end{tabular}

Berdasarkan Tabel 1, diperoleh nilai AIC dari model koreksi kesalahan Engle Granger lebih kecil dari model koreksi kesalahan Domowitz-Elbadawi. Hasil penelitian dari kedua model koreksi kesalahan menunjukkan bahwa model koreksi kesalahan Engle Granger merupakan model yang lebih baik digunakan dari model koreksi kesalahan Domowitz-Elbadawi.

\section{PENUTUP}

Berdasarkan pembahasan yang telah dilakukan maka dapat ditarik kesimpulan sebagai berikut:

1. Hasil estimasi model koreksi kesalahan pada kasus data runtun waktu indeks harga konsumen (IHK) berdasarkan empat kelompok pengeluaran di Kota Purwokerto Provinsi Jawa Tengah terlihat bahwa model koreksi kesalahan Engle Granger diperoleh nilai residual (-1) bertanda negatif dan signifikan. Sedangkan untuk model koreksi kesalahan Domowitz-Elbadawi diperoleh nilai $E C_{t-1}$ bertanda positif dan signifikan. Penerapan model koreksi kesalahan yang digunakan dalam penelitian ini adalah valid (sesuai) dan variabel yang diamati berkointegrasi, hal ini ditunjukkan oleh koefisien residual (-1) dan ECT yang signifikan.

2. Model koreksi kesalahan Engle Granger yang memiliki nilai AIC lebih kecil dari nilai AIC model koreksi kesalahan Domowitz- Elbadawi, sehingga dapat disimpulkan bahwa model koreksi kesalahan Engle Granger mempunyai kemampuan yang baik untuk data IHK berdasarkan empat kelompok pengeluaran. 


\section{DAFTAR PUSTAKA}

[1]. Rosadi, D. Ekonometrika dan Analisis Runtun Waktu Terapan. Yogyakarta: Andi; 2012.

[2]. Maruddani, D.A.,Wilandari, Y., dan Safitri, D.,Model Dinamik Pertumbuhan Ekonomi Indonesia Pasca Krisis Moneter; Suatu Pendekatan Koreksi Kesalahan (Model Koreksi Kesalahan). Jurnal Sains dan Matematika (JSM). 2007 ; 1 (15): 19-24.

[3]. Widarjono, A. Ekonometrika Pengantar dan Aplikasinya disertai Panduan EViews. Yogyakarta: UUPSTIM YKPN; 2013.

[4]. Badan Pusat Statistik Jawa Tengah. Di akses 24 Januari 2018, dari https://Jateng.bps.go.id.

[5]. Rusdi. Uji Akar-Akar Unit dalam Model Runtun Waktu Autoregressive. Statistika. 2011 ; 11(2): 67-78.

[6]. Engle, R.F., and Granger, W.J.Cointegration and Error Corection: Representation,Estimation and Testing. Econometrica. 1987 ; 55: 251-276.

[7]. Fathurahman, M., Pemilihan Model Regresi Terbaik Menggunakan Metode Akaike's Information Criterion dan Schwarz Information Criterion. Jurnal Matematika Mulawarman. 2009 ; 4(3) : 3134.

MEGA SARI

EVY SULISTIANINGSIH
: Jurusan Matematika FMIPA Untan, Pontianak, Mega.93sari@gmail.com : Jurusan Matematika FMIPA Untan, Pontianak, evysulistianingsih@math.untan.ac.id 